\title{
Endotoxin-induced cytokine and chemokine expression in the HIV-1 transgenic rat
}

\author{
Natasha F Homji ${ }^{1+}$, Xin Mao ${ }^{1+}$, Erik F Langsdorf ${ }^{1}$ and Sulie L Chang ${ }^{1,2^{*}}$
}

\begin{abstract}
Background: Repeated exposure to a low dose of a bacterial endotoxin such as lipopolysaccharide (LPS) causes immune cells to become refractory to a subsequent endotoxin challenge, a phenomenon known as endotoxin tolerance (ET). During ET, there is an imbalance in pro- and anti-inflammatory cytokine and chemokine production, leading to a dysregulated immune response. HIV-1 viral proteins are known to have an adverse effect on the immune system. However, the effects of HIV-1 viral proteins during ET have not been investigated.

Methods: In this study, HIV-1 transgenic (HIV-1Tg) rats and control F344 rats ( $\mathrm{n}=12$ ea) were randomly treated with 2 non-pyrogenic doses of LPS (LL) to induce ET, or saline (SS), followed by a high challenge dose of LPS (LL $+\mathrm{L}, \mathrm{SS}+\mathrm{L})$ or saline $(\mathrm{LL}+\mathrm{S}, \mathrm{SS}+\mathrm{S})$. The gene expression of 84 cytokines, chemokines, and their receptors in the brain and spleen was examined by relative quantitative PCR using a PCR array, and protein levels in the brain, spleen, and serum of 7 of these 84 genes was determined using an electrochemiluminescent assay.

Results: In the spleen, there was an increase in key pro-inflammatory (IL $1 \alpha$, IL-1 $\beta$, IFN- $\gamma$ ) and anti-inflammatory (IL10) cytokines, and inflammatory chemokines ( $\mathrm{C} C \mathrm{2}, \mathrm{CCl}$, and $\mathrm{CCl9}$,) in response to LPS in the SS+L and LL+L (ET) groups of both the HIV-1Tg and F344 rats, but was greater in the HIV-1Tg rats than in the F344. In the ET HIV-1Tg and F344 $(\mathrm{LL}+\mathrm{L})$ rats in the spleen, the LPS-induced increase in pro-inflammatory cytokines was diminished and that of the anti-inflammatory cytokine was enhanced compared to the SS+L group rats. In the brain, IL-1 $\beta$, as well as the $\mathrm{CCl} 2, \mathrm{CCl} 3$, and $\mathrm{CCl} 7$ chemokines were increased to a greater extent in the HIV-1Tg rats compared to the F344; whereas CxCl1, CxCl10, and CxCl11 were increased to a greater extent in the F344 rats compared to the HIV$1 \mathrm{Tg}$ rats in the $\mathrm{LL}+\mathrm{L}$ and $\mathrm{SS}+\mathrm{L}$ groups.
\end{abstract}

Conclusion: Our data indicate that the continuous presence of HIV-1 viral proteins can have tissue-dependent effects on endotoxin-induced cytokine and chemokine expression in the ET state.

Keywords: HIV-1 transgenic rat, endotoxin tolerance, cytokines, chemokines

\section{Background}

The bacterial endotoxin, lipopolysaccharide (LPS), is a well-characterized glycolipid component of the cell wall of gram-negative bacteria [1-3]. LPS is a model molecule commonly used to study the inflammatory responses caused by exposure to bacteria, in particular, the induction and actions of inflammatory cytokines and chemokines [4-6]. An inflammatory response involves a balance between the production of pro-inflammatory cytokines and chemokines and the subsequent

\footnotetext{
* Correspondence: sulie.chang@shu.edu

+ Contributed equally

'Institute of Neurolmmune Pharmacology, Seton Hall University, South Orange, NJ, 07079, USA

Full list of author information is available at the end of the article
}

production of anti-inflammatory cytokines [7]. An imbalance in this mechanism can lead to disastrous immune system-related consequences. Tight control of pro-inflammatory cytokine production is necessary in order to protect against septic shock. An imbalance in this regulatory mechanism can also lead to the development of endotoxin tolerance (ET) [8-14]. In ET, repeated exposure to minute amounts of an endotoxin, like LPS, causes immune cells, such as macrophages and monocytes, to become refractory to a subsequent highdose endotoxin challenge $[7,11,13,15-17]$. On re-exposure to an endotoxin, when the animal is in an ET state, there is an increase in production of anti-inflammatory cytokines and a decrease in production of pro-

\section{() Biomed Central}


inflammatory cytokines in comparison to a single exposure to the endotoxin [14]. ET is known to resemble immunosuppression in many aspects reported in patients with sepsis or non-infectious systemic inflammatory response syndrome (SIRS) [18]. While ET initially protects against severe infection and tissue damage by overt inflammatory response, however the immune dysregulation observed in ET and in SIRS patients is associated with greater propensity to succumb to nosocomial infections $[18,19]$.

The Human immunodeficiency virus-1 (HIV-1) is characterized by very rapid viral replication. The virus is subsequently transported to the lymphoid organs and the central nervous system (CNS). A very strong cellular and humoral immune response is evoked in the host within a few weeks [20], after which there is a clinical latency period, sometimes for years, followed by rapid clinical deterioration [21]. It is believed that the continued presence of HIV-1 viral proteins plays a role in the clinical progression of $\mathrm{HIV}-1$ infection to full-blown AIDS [22-26].

Since 1996, highly active anti-retroviral therapy (HAART) has resulted in a dramatic improvement in the health and longevity of HIV-infected individuals [27]. However, HAART drugs are limited in their capacity to enter the CNS and other organs that are protected by tight endothelial barriers. Thus, in this postHAART era, the clinical challenge is to identify the biological and physiological changes that occur due to the persistent presence of HIV-1 viral proteins in the host even when active viral replication is arrested [28,29].

Some HIV-1 viral proteins have been shown to affect the inflammatory response by altering the production of cytokines. For example, the HIV-1 Tat protein can alter the LPS-induced production of IFN- $\beta$ and IL- 6 in blood monocytes/macrophages [30], and HIV-1 Vpr suppresses IL-12 production in human monocytes [31]. However, the effects of HIV-1 viral proteins on immune function during a state of ET has not been examined.

The HIV-1 transgenic (HIV-1Tg) rat model was developed with a functional deletion of the gag and pol genes in the HIV-1 genome. It is, however, under the control of the viral promoter and expresses seven of the nine HIV genes [32]. Thus, in the HIV-1Tg rat, there is no HIV-1 replication, but other HIV-1 viral proteins are expressed [32]. We have shown that, like HIV-1 infected patients, the HIV-1Tg rat is immunodeficient. LPSinduced leukocyte-endothelial adhesion (LEA) is greatly attenuated in the HIV-1Tg rat [33]. In addition, the HIV-1Tg rat shows signs of wasting and dies at a younger age even though there is no growth retardation and no sign of anorexia throughout its life span [34]. These rats also have decreased alveolar macrophage zinc levels and phagocytosis [35]. The HIV-1Tg rat model, thus, exhibits some of the characteristics of HIV-1 infected patients given HAART [36-39].

There is an association between chronic HIV infection and elevated plasma endotoxin levels. Innate immune responses, which are dysregulated in ET, are also altered in HIV infection [40]. The cytokines/chemokines modulated during ET play a role in HIV infection, replication (not applicable for our model) and pathogenesis. Tolllike receptor 4 (TLR4) mediates gram-negative bacteria activated signaling and significant changes in this receptor's level is directly correlated with HIV infection [41]. TNF- $\alpha$ upregulation leads to HIV-induced cytotoxicity [42]. Enhanced levels of Ccl2 in HIV-1 patients have been associated with HIV-1-associated dementia [43]. The Center for Disease Control (CDC) has identified HIV-1 infection as a major reason for the increase in incidence of sepsis [44]. Opportunistic infections are a common feature in HIV-1 positive patients, who have a compromised immune status [45]. ET leads to a similar immunosuppressed state. Identifying the mechanism by which ET affects an already immune-compromised system, as in HIV-1 infection, could provide valuable information of clinical relevance. We hypothesized that the continuous presence of HIV-1 viral proteins alters the systemic immune response to bacterial endotoxins in terms of pro- and anti-inflammatory cytokine and chemokine expression, and that this altered immune response is exacerbated when the animal is in an ET state. Specifically, we hypothesized that the production of pro-inflammatory cytokines is diminished and antiinflammatory cytokine production is enhanced in the HIV-1Tg rat rendered endotoxin tolerant. To test this hypothesis, in this study, we examined the expression of an array of cytokines, chemokines, and their receptors in the serum, spleen, and brain of an endotoxin tolerant $\mathrm{HIV}-1 \mathrm{Tg}$ rat model in response to an LPS challenge.

\section{Methods \\ Animals}

Adolescent male Sprague-Dawley HIV-1 transgenic (HIV -1Tg) rats and age-matched Fisher/NHsd 344 (F344) control rats were purchased from Harlan Laboratories (Indianapolis, IN), and were delivered on postnatal day 28. The animals were group-housed immediately upon arrival, and stayed in group cages during the experiment. The animals were maintained in an environment of controlled temperature $\left(21-22^{\circ} \mathrm{C}\right)$ on a $12-\mathrm{h}$ light/12-h dark illumination cycle, with lights-on set at 7:00 AM. Food and tap water were provided ad libitum. The experimental protocol was approved by the Institutional Animal Care and Use Committee (IACUC) at Seton Hall University, South Orange, NJ. 


\section{Lipopolysaccharide (LPS) administration}

Dosing solutions of LPS were prepared in saline. In our preliminary studies using Harlan Sprague Dawley rats, we found that two intraperitoneal (i.p) injections with a non-pyrogenic dose $(250 \mu \mathrm{g} / \mathrm{kg}$ ea $)$ of LPS, administered 9-12 hrs apart, was the lowest dosage regimen that would cause endotoxin tolerance and inhibit the production of IL- $1 \beta$, TNF- $\alpha$, and IL- 6 in response to a subsequent challenge with a significantly higher dosage of LPS [1, 4, 8, 16, or $32 \mathrm{mg} / \mathrm{kg}$ ] (data not shown). In this study, HIV-1Tg and F344 rats $(\mathrm{n}=12$ ea, 19-20 wks old) were randomly assigned to four experimental groups ( $\mathrm{n}=3$ animals/group). At 8:00 AM and 5:00 PM on Day 1, Groups 1 and 2 received two i.p. injections of $250 \mu \mathrm{g} / \mathrm{kg}$ LPS each (LL); Groups 3 and 4 received two i.p. injections of saline (SS). At 8:00 AM on Day 2, Group 1 received one i.p. injection with $5 \mathrm{mg} / \mathrm{kg}$ LPS $(\mathrm{LL}+\mathrm{L})$; Group 2 received one i.p. injection with saline $(\mathrm{LL}+\mathrm{S})$; Group 3 received one i.p. injection with $5 \mathrm{mg} /$ kg LPS (SS+L); and Group 4 received one i.p. injection with saline $(\mathrm{SS}+\mathrm{S})$. The dosage of $5 \mathrm{mg} / \mathrm{kg}$ for the subsequent LPS injection was chosen based on previous studies using the HIV-1Tg rat model [46]. Two hours following the last injection, the brains, spleens, and blood were collected for RNA, protein, and serum preparation.

\section{Protein extraction from the brain and spleen}

Protein extracts were prepared from approximately 100 $\mathrm{mg}$ of brain and spleen tissue in a Tris lysis buffer containing $20 \mathrm{mM}$ Tris, $\mathrm{pH}$ 7.5, $1 \mathrm{mM}$ EDTA, $1 \mathrm{mM}$ EGTA, and $1 \mathrm{M} \mathrm{NaF}$ (all from Sigma Aldrich, St. Louis, $\mathrm{MO}$ ), and 1 tablet of Protease Inhibitor (Roche, Mannheim, Germany). The tissues were disrupted using the Branson Sonifier 250 (VWR, Radnor, PA) with $15 \mathrm{sec}$ bursts, a duty cycle setting of $40 \%$ (0.4 sec burst $/ 0.6 \mathrm{sec}$ pause), and an output of 4 . The concentration of protein from each of the tissue types was determined using the ProStain assay kit (Active Motif, Carlsbad, CA), and measured as fluorescence intensity against a BSA standard curve with the Spectra Max Gemini (Molecular Devices, Sunnyvale, CA).

\section{Measurement of inflammatory cytokines}

Protein levels of IL- $1 \beta, \mathrm{KC} / \mathrm{GRO}$, IL-4, IL-5, TNF- $\alpha$, IFN$\gamma$, and IL-13 were determined in undiluted serum and in extracts from $200 \mu \mathrm{g}$ of brain and spleen using a 96-well inflammatory cytokine kit [MesoScale Discovery (MSD), Gaithersberg, MD]. Measurement of electrochemiluminescent signal intensity was determined on the SECTOR 2400 instrument (MesoScale Discovery, Gaithersberg, $\mathrm{MD})$. Calibrator solutions were diluted 4-fold over a concentration range of $40,000 \mathrm{pg} / \mathrm{mL}$ to $9.8 \mathrm{pg} / \mathrm{mL}$.

\section{RNA isolation and preparation of CDNA}

Total RNA was extracted from brain and spleen homogenates using TRIZOL (Invitrogen, Carlsbad, CA). The extracts were then treated with Ambion ${ }^{\circledR}$ TURBO DNA-free ${ }^{\mathrm{TM}}$ (Ambion, Austin, TX) to remove contaminating DNA, and harvested using a RNeasy mini kit (Qiagen, Valencia, CA). RNA quality and quantity were assessed using a Nanodrop spectrophotometer. Equal amounts of RNA from each sample were then converted into first-strand cDNA using a RT2 First Strand Kit (SA Biosciences, Frederick, MD),

\section{Real-time PCR array}

Detection and quantification of gene expression were performed using a Rat Inflammatory Cytokines and Receptors PCR Array and $\mathrm{RT}^{2}$ SYBR Green Fluorescin qPCR Master (SA Biosciences, Frederick, MD) according to the manufacturer's instructions. This kit was chosen because it includes diverse genes important in immune responses, including genes encoding $\mathrm{CC}$ chemokines $(n=16)$, CXC chemokines $(n=9)$, interleukin cytokines $(n=14)$, other cytokines $(n=11)$, chemokine receptors $(\mathrm{n}=15)$, and cytokine receptors $(\mathrm{n}=11)$, as well as other genes involved in the inflammatory response $(\mathrm{n}=8)$.

Real-time PCR was performed using an ABI Prism 7900HT Fast Detection System (Applied Biosystems, Foster, CA). Each $10 \mu \mathrm{L}$ reaction was performed in a 384-well format PCR array. The PCR mix was denatured at $95^{\circ} \mathrm{C}$ for $10 \mathrm{~min}$ before the first PCR cycle. The thermocycler parameters were $95^{\circ} \mathrm{C}$ for $10 \mathrm{~min}$, followed by 40 cycles at $95^{\circ} \mathrm{C}$ for $15 \mathrm{~s}$, and $60^{\circ} \mathrm{C}$ for $1 \mathrm{~min}$.

\section{PCR array data analysis}

In order to be able to compare different PCR array results, the threshold and baseline values were set manually, according to the manufacturer's instructions, and the resulting threshold cycle value (CT) data were uploaded into the data analysis template on the manufacturer's website http://www.sabiosciences.com/pcr/ arrayanalysis.php. RNA expression of each gene was normalized using five housekeeping genes as controls. The relative expression of each gene, compared with the expression in the control group, was calculated on the website using the $\Delta \Delta C T$ method. A difference was considered significant at $p<0.05$. In the expression studies, a gene was considered differentially regulated if the difference was $>2$-fold compared with the control, and markedly differentially regulated if the difference was > 10-fold [47-52]. Each reported value represents the mean increase or decrease of mRNA expression relative to the levels for the controls from three biological replicates. 


\section{Statistical analysis}

Inflammatory cytokine protein level data in this study are presented as the mean \pm SD. Statistical analysis was done using Graphpad Prism 5.0. Differences among treatment groups were analyzed by a one-way ANOVA, followed by a Newman-Keuls post hoc test. The difference in the basal levels of cytokines/chemokines in the brain, spleen, and serum between F344 and HIV-1Tg rats was determined using the Student's t-test.

\section{Results}

Cytokine and chemokine protein expression in the serum, brain, and spleen of HIV-1Tg rats during endotoxin tolerance (ET)

The protein levels of IL- $1 \beta$, KC/GRO, IL-4, IL-5, TNF$\alpha$, IFN- $\gamma$, and IL-13 were determined in the brain, spleen, and sera of HIV-1Tg and F344 rats rendered ET $(\mathrm{LL})$, then challenged with either LPS $(\mathrm{LL}+\mathrm{L})$ or saline $(\mathrm{LL}+\mathrm{S})$, using an electrochemiluminescent (MSD) assay (Table 1, 2, 3). Saline-treated animals were used as controls $(\mathrm{SS}+\mathrm{S})$. There was no difference in the basal levels $(\mathrm{SS}+\mathrm{S}$ group levels) of the cytokines/chemokines measured in the serum in the two strains of animals (Table $1)$. In the F344 serum, the levels of the pro-inflammatory cytokine, IFN- $\gamma$, and the anti-inflammatory cytokines, IL-4 and IL-13, in the single exposure group (SS $+\mathrm{L}$ ) were significantly greater than in the control group $(\mathrm{SS}+\mathrm{S})$, and significantly less in the ET group $(\mathrm{LL}+\mathrm{L})$ than in the single exposure group $(\mathrm{SS}+\mathrm{L})$. In the HIV$1 \mathrm{Tg}$ serum, the levels of the pro-inflammatory cytokines,
IL- $1 \beta$, TNF- $\alpha$, and IFN- $\gamma$, and the anti-inflammatory cytokines, IL-4 and IL-13, in the single exposure group $(\mathrm{SS}+\mathrm{L})$ were significantly higher than in the control group $(\mathrm{SS}+\mathrm{S})$, and significantly lower in the ET group $(\mathrm{LL}+\mathrm{L})$ than in the single exposure group $(\mathrm{SS}+\mathrm{L})$ [Table 1].

The basal levels of IL-4 and TNF- $\alpha$ in the F344 rat brain, and IL-4, IL-5, and TNF- $\alpha$ in the HIV-1Tg brain, were not detectable by electrochemiluminescent (MSD) assay. The basal levels of cytokines/chemokines that were detectable in the brain were similar in both strains of animals (Table 2). An LPS challenge dose (SS+L and $\mathrm{LL}+\mathrm{L}$ ) did not significantly alter any of the cytokine/ chemokine levels in the F344 rat brain (Table 2). However, in the HIV-1Tg rat brain, the levels of the proinflammatory cytokines, IL- $1 \beta$ and IFN- $\gamma$, were significantly higher in the $\mathrm{SS}+\mathrm{L}$ group versus the control. The level of the pro-inflammatory cytokine, IFN- $\gamma$, was significantly lower in the LL+L group compared to the SS $+\mathrm{L}$ group (Table 2).

The basal level of TNF- $\alpha$ was not detectable in the spleen of either the F344 or HIV-1Tg rats (Table 3). There was no significant difference in the basal levels of any of the cytokines/chemokines that were detectable in the spleen of the F344 and HIV-1Tg rats, with the exception of IFN- $\gamma$, which was significantly greater in the F344 rat spleen compared to that in the HIV-1Tg rat spleen (Table 3). In the F344 spleen, the levels of the pro-inflammatory cytokines, IL- $1 \beta$ and IFN- $\gamma$, and the anti-inflammatory cytokines, IL- 4 and IL-13, in the

Table 1 Cytokine/Chemokine Profiles in F344 and HIV-1Tg Rat Serum

\begin{tabular}{|c|c|c|c|c|c|c|c|}
\hline \multicolumn{8}{|c|}{ Cytokines and Chemokines in the Serum with LPS Treatment } \\
\hline \multirow{3}{*}{ F344 } & \multicolumn{7}{|c|}{ Protein $(\mathrm{pg} / \mathrm{ml}, \pm \mathrm{SD})$} \\
\hline & $\| \mathrm{L}-1 \beta$ & KC/GRO & $\mathrm{IL}-4$ & $\mathrm{IL}-5$ & TNF- $\alpha$ & $\mathrm{IFN}-\gamma$ & $\mathrm{IL}-13$ \\
\hline & $\begin{array}{l}\text { Interleukin } 1 \\
\text { beta }\end{array}$ & & Interleukin 4 & Interleukin 5 & $\begin{array}{c}\text { Tumor necrosis factor - } \\
\text { alpha }\end{array}$ & $\begin{array}{l}\text { Interferon } \\
\text { gamma }\end{array}$ & $\begin{array}{c}\text { Interleukin } \\
13\end{array}$ \\
\hline $\mathrm{SS}+\mathrm{S}$ & $83.0( \pm 21.3)$ & $1294.8( \pm 589.7)$ & $9.5( \pm 0.6)$ & $116.0( \pm 23.7)$ & $42.7( \pm 6.1)$ & $35.2( \pm 7.2)$ & $27.5( \pm 1.1)$ \\
\hline $\mathrm{SS}+\mathrm{L}$ & $272.1( \pm 145.1)$ & $7153.2( \pm 2779.8)^{* *}$ & $\underset{* * *}{15.5( \pm 1.7)}$ & $\begin{array}{c}348.7( \pm \\
202.4)\end{array}$ & $7531.8( \pm 7897.0)$ & $138.6( \pm 46.2)^{* *}$ & $\underset{* *}{42.3( \pm 9.5)}$ \\
\hline $\mathrm{LL}+\mathrm{S}$ & $80.4( \pm 42.4)$ & $780.9( \pm 846.6)$ & $10.3( \pm 51.2)$ & $103.6( \pm 32.6)$ & $51.2( \pm 12.4)$ & $56.5( \pm 19.6)$ & $22.5( \pm 1.1)$ \\
\hline $\mathrm{LL}+\mathrm{L}$ & $125.1( \pm 23.5)$ & $3293.5( \pm 680.6)^{*}$ & $\begin{array}{c}11.1( \pm 1.1) \\
\wedge \wedge\end{array}$ & $210.0( \pm 56.7)$ & $88.2( \pm 25.5)$ & $61.8( \pm 18.9)^{\wedge \wedge}$ & $26.5( \pm 2.1)^{\wedge}$ \\
\hline \multirow{2}{*}{$\begin{array}{l}\text { HIV - } \\
1 \mathrm{Tg}\end{array}$} & $\| L-1 \beta$ & $\mathrm{KC} / \mathrm{GRO}$ & $\mathrm{IL}-4$ & $\mathrm{IL}-5$ & $\mathrm{TNF}-\alpha$ & $\mathrm{IFN}-\gamma$ & $\mid \mathrm{L}-13$ \\
\hline & $\begin{array}{l}\text { Interleukin } 1 \\
\text { beta }\end{array}$ & & Interleukin 4 & Interleukin 5 & $\begin{array}{c}\text { Tumor necrosis factor - } \\
\text { alpha }\end{array}$ & $\begin{array}{l}\text { Interferon } \\
\text { gamma }\end{array}$ & $\begin{array}{c}\text { Interleukin } \\
13\end{array}$ \\
\hline $\mathrm{SS}+\mathrm{S}$ & $85.2( \pm 31.6)$ & 1907.4(土 978.9) & $10.7( \pm 2.0)$ & $154.7( \pm 83.6)$ & $45.2( \pm 11.4)$ & $67.8( \pm 32.2)$ & $26.8( \pm 0.5)$ \\
\hline $\mathrm{SS}+\mathrm{L}$ & $\begin{array}{c}307.4( \pm 72.9) \\
* * *\end{array}$ & $7002.2( \pm 361.0)^{* * *}$ & $14.4( \pm 2.5)$ & $258.3( \pm 37.3)$ & $2366.7( \pm 924.4)^{* * *}$ & $122.3( \pm 13.4)^{*}$ & $36.2( \pm 6.6)^{*}$ \\
\hline $\mathrm{LL}+\mathrm{S}$ & $47.9( \pm 7.4)$ & $327.6( \pm 110.5)$ & $8.0( \pm 1.4)$ & $29.7( \pm 34.3)$ & $42.8( \pm 7.0)$ & $18.3( \pm 24.9)$ & $22.3( \pm 1.1)$ \\
\hline $\mathrm{LL}+\mathrm{L}$ & $128.6( \pm 3.0)^{\wedge \wedge \wedge}$ & $\begin{array}{c}3051.3( \pm 1215.7) \\
\wedge \wedge \wedge\end{array}$ & $\begin{array}{c}11.3( \pm 0.8) \\
\wedge \wedge\end{array}$ & $\begin{array}{c}189.1( \pm \\
121.1)\end{array}$ & $113.4( \pm 51.8)^{\wedge \wedge \wedge}$ & $71.1( \pm 9.1)^{\wedge}$ & $27.9( \pm 4.2)^{\wedge}$ \\
\hline
\end{tabular}


Table 2 Cytokine/Chemokine Profiles in the F344 and HIV-1Tg Rat Brain

\begin{tabular}{|c|c|c|c|c|c|c|c|}
\hline \multicolumn{8}{|c|}{ Cytokines and Chemokines in the Brain with LPS Treatment } \\
\hline & & & & Protein $(\mathrm{pg} /$ & $\mathrm{nl}, \pm \mathrm{SD})$ & & \\
\hline \multirow[t]{2}{*}{ F344 } & $\| \mathrm{L}-1 \beta$ & $\mathrm{KC} / \mathrm{GRO}$ & $\mathrm{IL}-4$ & IL-5 & TNF- $\alpha$ & $\mathrm{IFN}-\gamma$ & $\mathrm{IL}-13$ \\
\hline & Interleukin 1 beta & & Interleukin 4 & Interleukin 5 & Tumor necrosis factor - alpha & Interferon gamma & Interleukin 13 \\
\hline$S S+S$ & $42.2( \pm 8.8)$ & $74.4( \pm 23.3)$ & ND & $56.5( \pm)$ & ND & $15.3( \pm 7.5)$ & $4.4( \pm 1.8)$ \\
\hline $\mathrm{SS}+\mathrm{L}$ & $178.4( \pm 162.1)$ & $1325.3( \pm 1431.3)$ & 13.5) & $102.8( \pm 61.1)$ & 30.9 & $20.5( \pm 11.9)$ & $4.8( \pm 3.1)$ \\
\hline $\mathrm{LL}+\mathrm{S}$ & $59.1( \pm 26.3)$ & $112.6( \pm 35.6)$ & 3.4 & 74.7 & ND & $14.7( \pm 7.0)$ & $6.9( \pm 1.4)$ \\
\hline $\mathrm{LL}+\mathrm{L}$ & $207.0( \pm 133.0)$ & $1036.2( \pm 685.6)$ & $2.9( \pm 1.3)$ & $141.9( \pm 98.3)$ & ND & $21.9( \pm 6.5)$ & $5.3( \pm 2.3)$ \\
\hline \multirow[t]{2}{*}{ HIV - 1Tg } & $I L-1 \beta$ & $\mathrm{KC} / \mathrm{GRO}$ & $\mathrm{IL}-4$ & IL-5 & TNF- $\alpha$ & $\mathrm{IFN}-\gamma$ & IL-13 \\
\hline & Interleukin 1 beta & & Interleukin 4 & Interleukin 5 & Tumor necrosis factor - alpha & Interferon gamma & Interleukin 13 \\
\hline $\mathrm{SS}+\mathrm{S}$ & $37.3( \pm 17.1)$ & $125.3( \pm 87.8)$ & ND & ND & ND & $11.7( \pm 5.2)$ & $5.1( \pm 0.4)$ \\
\hline $\mathrm{SS}+\mathrm{L}$ & $361.7( \pm 104.6)^{*}$ & 2991.3( \pm 491.5$)^{* *}$ & $9.2( \pm 3.1)$ & $164.2( \pm 35.3)$ & 109.5 & $47.1( \pm 14.5)^{*}$ & $9.3( \pm 4.2)$ \\
\hline $\mathrm{LL}+\mathrm{S}$ & $56.5( \pm 15.1)$ & $128.1( \pm 61.6)$ & ND & ND & ND & $8.9( \pm 5.9)$ & $4.6( \pm 1.4)$ \\
\hline$L L+L$ & $208.6( \pm 167.4)$ & $1312.9( \pm 1039.2)^{\wedge}$ & $8.1( \pm 1.6)$ & $181.2( \pm 50.0)$ & 27.3 & $24.3( \pm 14.5)^{\wedge}$ & $7.3( \pm 3.7)$ \\
\hline
\end{tabular}

${ }^{*} P<0.05$, ** $P<0.01,{ }^{* * *} P<0.001$ greater $\mathrm{SS}+\mathrm{S}$ control; $\wedge P<0.05, \wedge \wedge P<0.01, \wedge \wedge \wedge \mathrm{P}<0.001$ less than $\mathrm{SS}+\mathrm{L}$; statistically significant changes are bolded

single exposure group $(\mathrm{SS}+\mathrm{L})$ were significantly higher than in the control. In the F344 rats, the levels of the pro-inflammatory cytokines, IL- $1 \beta$ and IFN- $\gamma$, and the anti-inflammatory cytokine, IL-4, were significantly lower in the spleen of the LL+L group compared to the single exposure group (SS+L). In the HIV-1Tg spleen, the levels of the pro-inflammatory cytokines, IL- $1 \beta$ and IFN- $\gamma$, and the anti-inflammatory cytokine, IL-4, were significantly higher in the single exposure group $(\mathrm{SS}+\mathrm{L})$ and in the endotoxin tolerant group ( $\mathrm{LL}+\mathrm{L})$ compared to the control. In the LL+L group of HIV-1Tg rats, the pro-inflammatory cytokines, IL-1 $1 \beta$ and IFN $-\gamma$, and the anti-inflammatory cytokine, IL-4, were significantly lower than in the single exposure $(\mathrm{SS}+\mathrm{L})$ group (Table $3)$.

Expression profiles of cytokines, cytokine-receptors, and other inflammatory molecules in the brain and spleen of the HIV-1Tg rat following LPS treatment

The gene expression profiles of an array of cytokines, cytokine receptors, and other inflammatory molecules were determined in the brain and spleen of the three

Table 3 Cytokine/Chemokine Profiles in the F344 and HIV-1Tg Rat Spleen

\begin{tabular}{|c|c|c|c|c|c|c|c|}
\hline \multicolumn{8}{|c|}{ Cytokines and Chemokines in the Spleen with LPS Treatment } \\
\hline & & & & otein $(\mathrm{pg} / \mathrm{ml}, \pm$ & SD) & & \\
\hline \multirow[t]{2}{*}{ F344 } & $\mathrm{IL}-1 \beta$ & $\mathrm{KC} / \mathrm{GRO}$ & $\mathrm{IL}-4$ & IL-5 & TNF- $\alpha$ & $\mathrm{IFN}-\gamma$ & IL-13 \\
\hline & Interleukin 1 beta & & Interleukin 4 & Interleukin 5 & $\begin{array}{c}\text { Tumor necrosis factor - } \\
\text { alpha }\end{array}$ & $\begin{array}{l}\text { Interferon } \\
\text { gamma }\end{array}$ & $\begin{array}{l}\text { Interleukin } \\
13 \\
\end{array}$ \\
\hline SS+S & $1802.9( \pm 635.7)$ & $264.7( \pm 122.7)$ & $6.9( \pm 3.3)$ & 119.5( \pm 20.0$)$ & ND & $34.5( \pm 13.6)$ & $3.7( \pm 2.3)$ \\
\hline SS+L & $\begin{array}{l}19030.7( \pm \\
11365.4)^{*}\end{array}$ & $20065.6( \pm 11858.1)$ & $50.7( \pm 16.0)$ & $\underset{* *}{344.4( \pm 83.9)}$ & $2943.6( \pm 2752.3)$ & $203.3( \pm 71.5)^{* *}$ & $\underset{* *}{22.1( \pm 6.0)}$ \\
\hline $\mathrm{LL}+\mathrm{S}$ & $3325.3( \pm 440.6)$ & $506.6( \pm 205.0)$ & $6.8( \pm 5.7)$ & $120.0( \pm 28.8)$ & ND & $32.5( \pm 28.1)$ & $3.8( \pm 3.0)$ \\
\hline $\mathrm{LL}+\mathrm{L}$ & 7898( $( \pm 1996.9)^{\wedge}$ & $11818.7( \pm 9648.2)$ & $\begin{array}{c}21.6( \pm 10.2) \\
\wedge \wedge\end{array}$ & $246.6( \pm 79.4)$ & $228.7( \pm 19.6)$ & $105.3( \pm 45.0)^{* \wedge}$ & $14.2( \pm 6.1)$ \\
\hline \multirow{2}{*}{$\begin{array}{c}\text { HIV - } \\
1 \mathrm{Tg}\end{array}$} & $\| \mathrm{L}-1 \beta$ & $\mathrm{KC} / \mathrm{GRO}$ & $\mid \mathrm{L}-4$ & IL-5 & TNF- $\alpha$ & $\mathrm{IFN}-\gamma$ & IL-13 \\
\hline & Interleukin 1 beta & & Interleukin 4 & Interleukin 5 & Tumor necrosis factor $-\alpha$ & $\begin{array}{l}\text { Interferon } \\
\text { gamma }\end{array}$ & $\begin{array}{l}\text { Interleukin } \\
13\end{array}$ \\
\hline$S S+S$ & $1274.5( \pm 122.3)$ & $361.1( \pm 187.7)$ & $3.8( \pm 1.4)$ & $107.7( \pm 33.0)$ & ND & $10.8( \pm 4.8)$ & $0.8( \pm 0.7)$ \\
\hline$S S+L$ & $\underset{* *}{19951.8( \pm 4023.8)}$ & $\underset{* *}{25812.5( \pm 3014.5)}$ & $41.8( \pm 5.7)^{* *}$ & $\underset{* *}{395.4( \pm 93.3)}$ & $2755.4( \pm 1596.0)$ & $296.9( \pm 83.4)^{* *}$ & $32.0( \pm 4.9)^{*}$ \\
\hline $\mathrm{LL}+\mathrm{S}$ & $5087.1( \pm 1675.4)$ & $961.8( \pm 89.1)$ & $7.3( \pm 2.0)$ & $178.4( \pm 57.2)$ & ND & $19.8( \pm 2.6)$ & $6.6( \pm 6.4)$ \\
\hline $\mathrm{LL}+\mathrm{L}$ & $11443.1( \pm 7400)^{* \wedge}$ & $\begin{array}{l}12754.4( \pm \\
11613.3)^{\wedge}\end{array}$ & $\underset{\substack{27.3 \\
* \wedge}}{* 12.6)}$ & $\underset{\wedge}{239.4( \pm 77.1)}$ & $356.7( \pm 149.4)$ & $151.5( \pm 77.6)^{* \wedge}$ & $19.8( \pm 11.4)$ \\
\hline
\end{tabular}


LPS treatment groups $(\mathrm{SS}+\mathrm{L}, \mathrm{LL}+\mathrm{S}$, and $\mathrm{LL}+\mathrm{L})$ and compared to the control group $(\mathrm{SS}+\mathrm{S})$ of both the HIV$1 \mathrm{Tg}$ and F344 rats (Figure 1). In the F344 and HIV-1Tg rat brain, the level of the pro-inflammatory cytokine, IL-
$1 \beta$, was elevated in the $\mathrm{LL}+\mathrm{L}$ (> 9 fold) and $\mathrm{SS}+\mathrm{L}(>4$ fold) groups. The level of the anti-inflammatory cytokine, IL-10, was elevated in the brain of both the SS+L ( $>3$ fold) and LL+L (> 2 fold) groups in the F344 rats,

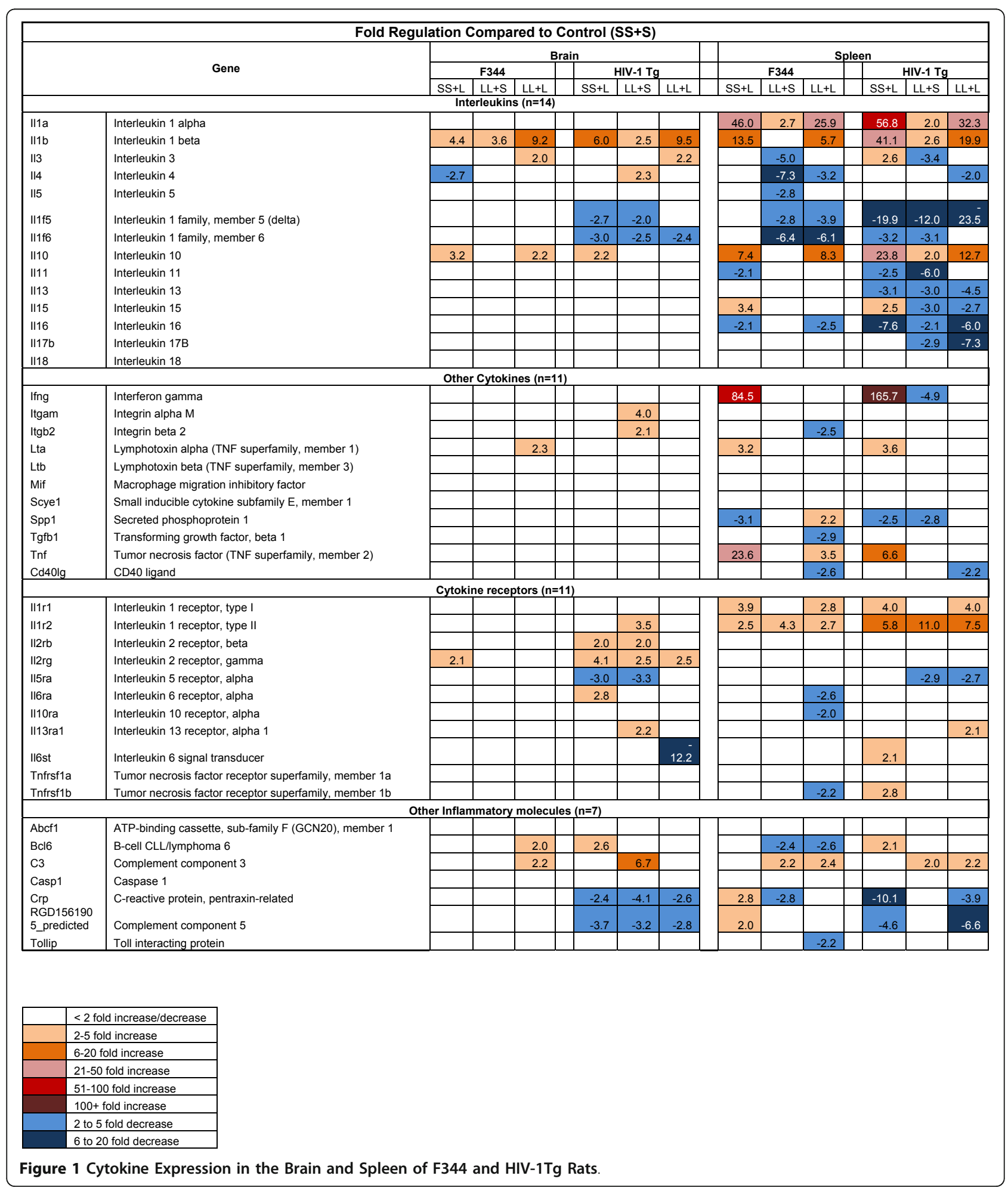


but only in the brain of the SS+L ( $>2$ fold) group in the HIV-1Tg rat brain (Figure 1). In the spleen of the F344 and HIV-1Tg rats, the levels of the pro-inflammatory cytokines, IL-1 $\alpha$, IL- $1 \beta$, were elevated in both the SS $+\mathrm{L}$ (> 10 fold) and LL+L (> 5 fold) groups. The levels of the pro-inflammatory cytokines, IFN- $\gamma$ and TNF- $\alpha$, were increased in the SS+L group ( $>6$ fold), and the antiinflammatory cytokine, IL-10, was higher in the SS+L (> 5 fold) and LL+L (> 7 fold) groups (Figure 1).

\section{Expression profiles of chemokine and chemokine receptors in the brain and spleen of the HIV-1Tg rat following LPS treatment}

The gene expression profiles of various chemokines and chemokine receptors were examined in the three LPS treatment groups and compared to the control group $(\mathrm{SS}+\mathrm{S})$ in both the HIV-1Tg and F344 rats (Figure 2). The gene expression of the inflammatory cc chemokines, $\mathrm{Ccl} 2, \mathrm{Ccl} 3, \mathrm{Ccl} 7$, and $\mathrm{Ccl} 20$, and inflammatory Cxc chemokines, Cxcl1, Cxcl2, and Cxcl10, were upregulated in the brain and spleen in the $\mathrm{SS}+\mathrm{L}$ and $\mathrm{LL}+\mathrm{L}$ groups of both the F344 and HIV-1Tg rats. The gene expression of the inflammatory cc chemokines, Ccl11 and Ccl24, were down-regulated in the brain of the LL $+\mathrm{L}$ group of both the F344 and HIV-1Tg rats, and in the $\mathrm{SS}+\mathrm{L}$ and $\mathrm{LL}+\mathrm{L}$ groups in the spleen of the HIV$1 \mathrm{Tg}$ rats.

Ten of the $15(10 / 15)$ chemokine receptors studied were down-regulated in the LL+L group of the spleen of the F344 rats. One of $15(1 / 15)$ and three of $15(3 / 15)$ chemokine receptors were down-regulated in the $\mathrm{LL}+\mathrm{L}$ group of the brain of the F344 and HIV-1Tg rats, respectively; ten of $15(10 / 15)$ and two of $15(2 / 15)$ chemokine receptors were diminished in the $\mathrm{LL}+\mathrm{L}$ group of the spleen of the F344 and HIV-1Tg rats (Figure 2).

\section{Discussion}

Endotoxin tolerance (ET) is a phenomenon in which previous exposure of cells or organisms to microbial products, such as the endotoxin, LPS, induces a transient period of hypo-responsiveness to a subsequent endotoxin challenge. Exposure to an endotoxin initiates the production of pro-inflammatory cytokines and a subsequent production of anti-inflammatory cytokines by immune cells $[7,15,53,54]$. ET is characterized by diminished release of pro-inflammatory cytokines, such as IL-1 $\beta$, IL- $1 \alpha$, and TNF- $\alpha$, and increased expression of anti-inflammatory cytokines, such as $1 \mathrm{~L}-$ 10 [14]. This negative feedback mechanism is important for protecting the host from tissue damage and death caused by excessive inflammation The differential expression of cytokines/chemokines in different tissues and at different times has been examined in Sprague Dawley rats to investigate the modulation of immune responses [46].
The occurrence of ET has been shown to increase the incidence of several diseases, including sepsis, pancreatitis, trauma and surgery [55]. The CDC has identified the increase of HIV-1 positive population as a major factor in the increased incidence of sepsis [44]. Studies have shown that the presence of HIV viral proteins causes a compromised immune response in HIV-1 patients [56-60]. The phenomenon of ET during HIV-1 infection has not been studied through animal models. Reid and colleagues [32] established a non-infectious HIV-1 transgenic (HIV-1Tg) rat model that expresses an HIV-1 provirus regulated by the viral promoter, but with a functional deletion of gag and pol. The characteristics of the HIV-1Tg rat include immunologic dysfunction, nephropathy, muscle wasting, skin lesions, and cataracts. We studied the systemic effect of the concurrent presence HIV-1 viral proteins and ET on the inflammatory response to bacterial endotoxin using the HIV-1Tg rat model. We examined the LPS-induced gene expression of 84 cytokines, chemokines, and their receptors in the blood, brain, and spleen of the endotoxin tolerant HIV$1 \mathrm{Tg}$ rat. Based on previous studies, we used two injections of a low dose of LPS $(250 \mu \mathrm{g} / \mathrm{kg})$ administered $9 \mathrm{~h}$ apart to induce ET, and a challenge injection with a high dose of LPS $(5 \mathrm{mg} / \mathrm{kg}) 12 \mathrm{~h}$ later. A single exposure to a high dose of endotoxin should cause a significant increase in the levels of pro-inflammatory and antiinflammatory cytokines compared to control [46]. In the ET state, when animals are exposed to repeated low doses of endotoxin, upon a subsequent challenge with a high dose of the endotoxin, one would expect that the increase in the pro-inflammatory cytokine levels would be lower compared to that in the single high dose exposure group [14]. To confirm that the animals were in the ET state, we measured the protein levels of inflammatory cytokines after the LPS challenge dose. Although the basal levels in the brain, spleen, and serum of the control groups $(\mathrm{SS}+\mathrm{S})$ of F344 and HIV-1Tg rats were similar, the changes in the cytokine and chemokine profiles in response to LPS were different in the HIV-1Tg and F344 rats. We found that, during ET, there was a significantly diminished expression of pro-inflammatory cytokines, such as IL- $1 \beta$, IFN- $\gamma$, and TNF- $\alpha$, in response to LPS $(\mathrm{LL}+\mathrm{L})$ compared to a single exposure of LPS $(\mathrm{SS}+\mathrm{L})$.

Of particular interest was the finding that the basal level of IFN- $\gamma$ in the spleen was lower in the SS+S group of HIV-1Tg rats than of the F344 rats, but was significantly increased in the $\mathrm{SS}+\mathrm{L}$ and $\mathrm{LL}+\mathrm{L}$ groups of the HIV-1Tg rats compared to the F344 rats (Table 3). A recent study showed that IFN- $\gamma$ countered ET by facilitating Toll-like receptor (TLR)-induced chromatin remodeling [61]. ET was prevented in IFN- $\gamma$ pre-treated primary human monocytes, and production of pro- 

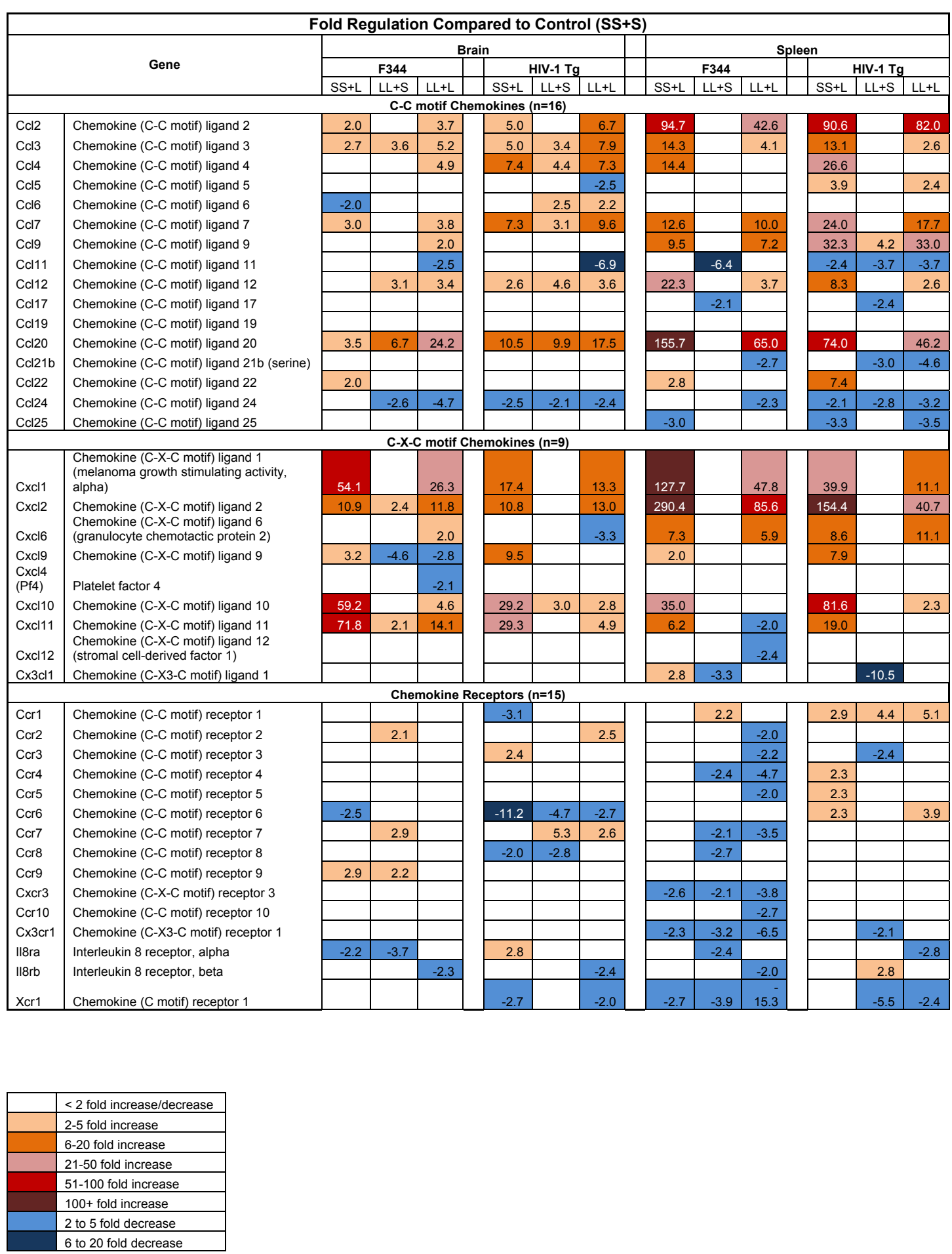

Figure 2 Chemokine Expression in the Brain and Spleen of F344 and HIV-1Tg Rats.

inflammatory cytokines, such as TNF- $\alpha$ and IL-6, was restored by facilitating TLR-induced chromatin remodeling [61]. It would be interesting to examine what role IFN $-\gamma$ plays in the restoration of the production of pro- inflammatory cytokines at the transcriptional level in the HIV-1Tg rat compared to control.

We found that, in both the ET state and after a single exposure to LPS, there was an altered response to LPS 
in terms of pro-inflammatory cytokine production in the spleen of the HIV-1Tg rats compared to the F344 rats. The expression level of the pro-inflammatory cytokines, IL- $1 \alpha$, IL-1 $\beta$, and IFN- $\gamma$, was 4- to 82 -fold greater in the spleen of the HIV-1Tg rats compared to the F344 rats in both the single LPS exposure $(\mathrm{SS}+\mathrm{L})$ and ET $(\mathrm{LL}+\mathrm{L})$ groups, indicating that the presence of viral proteins may have an effect on innate immune responses. There was also a difference in the expression of cytokine receptors in the brain of the HIV-1Tg rats compared to the F344 rats in response to LPS in both the ET state and after a single exposure to LPS, suggesting that HIV1 viral proteins may interact with or work through cytokine receptors in the brain. These data warrant further investigation into the neuroimmune effects of HIV-1 viral proteins.

During ET, the production of pro-inflammatory cytokines, such as IL-1 $\beta$, IL- 4 , and IL-5, in response to LPS $(\mathrm{LL}+\mathrm{L})$ was diminished in contrast to that elicited by a single exposure to the endotoxin ( $\mathrm{SS}+\mathrm{L})$. This altered response was seen in the spleen and serum in both the HIV-1Tg and F344 ET rats.

The spleen is an immune system organ, and, as such, one would expect that a greater number of cytokine and chemokine genes would be changed in the spleen in response to an immune challenge compared to the brain, and that is what we found in this study. In both the HIV-1Tg and F344 rats, there was a greater response to LPS in the spleen than in the brain.

Chemokines and their receptors have been implicated in the neuropathogenesis of HIV-1 infection [62]. There were significant differences in chemokine expression in response to LPS in the HIV-1Tg rats compared to the F344 rats. Enhanced levels of Ccl2 in HIV-1 patients have been associated with HIV-1-associated dementia [43]. Our results indicate that $\mathrm{Ccl} 2$ levels were increased to a greater extent (3- to 5 -fold) in the brain of the SS $+\mathrm{L}$ and $\mathrm{LL}+\mathrm{L}$ groups of HIV-1Tg rats versus the F344 rats, corroborating the role of upregulation of $\mathrm{Ccl} 2$ and its implications on HIV encephalopathy. The levels of the inflammatory CXC chemokines, Cxcl1, Cxcl2, Cxcl10, and Cxcl11, were elevated to a greater extent (0.1 - to 40 -fold) in the brain of the $\mathrm{SS}+\mathrm{L}$ and $\mathrm{LL}+\mathrm{L}$ groups of the F344 rats compared to the HIV-1Tg rats. $\mathrm{Ccl} 2$, Ccl7, and $\mathrm{Ccl} 9$, levels were increased to a greater extent in the SS+L and LL+L groups of the spleen of the HIV-1Tg rats in comparison to the F344 rats. Cxcl1 and Cxcl2 levels were elevated to a lesser extent in the spleen of the SS+L and LL+L groups of the F344 rats compared to the HIV-1Tg rats.

Chemokines and chemokine receptors define a network throughout the body, playing critical roles in immune and inflammatory responses as well as in many pathological processes, in diseases such as multiple sclerosis, Alzheimer's disease, and HIV/AIDS [63]. Cxcr4 and Ccr5 are reported to be co-receptors that mediate HIV-1 entry [64]. In our study, the gene expression of the chemokine receptors, Ccr2, Ccr3, Ccr4, Ccr5, Ccr7, Cxcr3, Ccr10, Ccr3, Cx3cr1, IL-8r $\beta$, and Xcr1, in the spleen of the ET group $(\mathrm{LL}+\mathrm{L})$ of F344 rats were down-regulated, whereas those in the HIV-1Tg spleen were not significantly different compared to the control group $(\mathrm{SS}+\mathrm{S})$. All these receptors have been shown to function as co-receptors for HIV-1infection in vitro [65], which suggests that HIV-1 viral proteins may interact with these chemokine receptors in vivo. There is also evidence that chemokines and chemokine receptors play an important part in the signaling of neuroprotective effects in the brain [63].

In this study, we noted a distinct pattern of cytokine/ chemokine expression in the brain, spleen, and serum of the HIV-1Tg and F344 rats in response to LPS, both with and without ET. Identifying these distinct cytokine/ chemokine profiles may potentially be useful as indicators of the onset and/or progression of certain disease processes, such as sepsis. Further studies will be done to determine the relationship of viral protein expression to the production of cytokines and chemokines during ET.

\section{Conclusions}

The data from our study provide a comprehensive picture of the neuroimmune responses to infection during ET, and strongly suggest that the presence of HIV-1 viral proteins may exacerbate those responses. These findings also suggest the potential use of experimentally defined cytokine/chemokine expression profiles as indicators of altered immune function in various disease states.

\section{Abbreviations}

Abcf1: ATP-binding cassette, sub-family F (GCN20), member 1; AIDS Acquired Immune Deficiency Syndrome; Bcl6: B-cell CLL/lymphoma 6; C3: Complement component 3; Casp1: Caspase 1; CCl11: Chemokine (C-C motif) ligand 11; CCl12: Chemokine (C-C motif) ligand 12; CCl17: Chemokine (C-C motif) ligand 17; CCl19: Chemokine (C-C motif) ligand 19; CCl2: Chemokine (C-C motif) ligand 2; Ccl20: Chemokine (C-C motif) ligand 20; Ccl21 b: Chemokine (C-C motif) ligand 21b; CcI22: Chemokine (C-C motif) ligand 22; CC124: Chemokine (C-C motif) ligand 24; CCl25: Chemokine (C-C motif) ligand 25; CCl3: Chemokine (C-C motif) ligand 3; Ccl4: Chemokine (C-C motif) ligand 4; C Cl5: Chemokine (C-C motif) ligand 5; Ccl6: Chemokine (C-C motif) ligand 6; C Cl7: Chemokine (C-C motif) ligand 7; C $\mathrm{Cl}$ : Chemokine (C-C motif) ligand 9; Ccr1: Chemokine (C-C motif) receptor 1; Ccr1: Chemokine (C-C motif) receptor 1; Ccr1: Chemokine (C-C motif) receptor 1; Ccr10: Chemokine (C-C motif) receptor 10; Ccr2: Chemokine (C-C motif) receptor 2; Ccr3: Chemokine (C-C motif) receptor 3; Ccr4: Chemokine (C-C motif) receptor 4; Ccr5: Chemokine (C-C motif) receptor 5; Ccr6: Chemokine (C-C motif) receptor 6; C Cr7: Chemokine (C-C motif) receptor 7; Ccr8: Chemokine (C-C motif) receptor 8; Ccr9: Chemokine (C-C motif) receptor 9; Cd40lg: CD40 ligand; CNS: Central nervous system; Crp: C-reactive protein, pentraxin-related; $C T$ : Threshold cycle value; Cxcl1: Chemokine (C-X-C motif) ligand 1 (melanoma growth stimulating activity, alpha); $\mathrm{C} \times 3 \mathrm{Cl} 1$ : Chemokine (C-X3-C motif) ligand 1; Cx3cr1: Chemokine (C-X3-C motif) receptor 1; Cxcl10: Chemokine (C-X-C motif) ligand 10; Cxcl11: Chemokine (C-X-C motif) ligand 11; Cxcl12: 
Chemokine (C-X-C motif) ligand 12; CxCl2: Chemokine (C-X-C motif) ligand 2; Cxcl4 (Pf4): Platelet factor 4; Cxcl6: Chemokine (C-X-C motif) ligand 6 (granulocyte chemotactic protein 2); Cxcl9: Chemokine (C-X-C motif) ligand 9; Cxcr3: Chemokine (C-X-C motif) receptor 3; ET: Endotoxin Tolerance; F344: Fisher/NHsd 344 control rats; HAART: Highly active anti-retroviral therapy; HIV-1: Human immunodeficiency virus-1; HIV-1Tg: HIV-1 Transgenic; IACUC: Institutional Animal Care and Use Committee; IFN- $\beta$ : Interferon beta; IFN- - : Interferon Gamma; IL-10: Interleukin 10; IL-10ra: Interleukin 10 receptor, alpha; IL-11: Interleukin 11; IL-12: Interleukin 12; IL-13: Interleukin 13; IL-13ra1: Interleukin 13 receptor alpha 1; IL-15: Interleukin 15; IL-16: Interleukin 16; IL17B: Interleukin 17B; IL-18: Interleukin 18; IL-1F5: Interleukin 1 family, member 5 (delta); IL-1F6: Interleukin 1 family, member 6; IL-1r1: Interleukin 1 receptor, type I; IL-1r2: Interleukin 1 receptor, type II; IL-1a: Interleukin 1, alpha; IL-1 1 : Interleukin 1, beta; IL-2rß: Interleukin 2 receptor, beta; IL-2ry: Interleukin 2 receptor, gamma; IL-3: Interleukin 3; IL-4: Interleukin 4; IL-5: Interleukin 5; IL5ra: Interleukin 5 receptor, alpha; IL-6: Interleukin 6; IL-6ra: Interleukin 6 receptor, alpha; IL-6st: Interleukin 6 signal transducer; IL-8ra: Interleukin 8 receptor, alpha; IL-8rß: Interleukin 8 receptor, beta; Itgam: Integrin alpha M; Itgb2: Integrin beta 2; LEA: LPS-induced leukocyte-endothelial adhesion; LPS: Lipopolysaccharide; Lta: Lymphotoxin alpha (TNF superfamily, member 1); Ltb: Lymphotoxin beta (TNF superfamily, member 3); Mif: Macrophage migration inhibitory factor; PCR: Polymerase chain reaction;

RGD1561905_predicted: Complement component 5; Scye1: Small inducible cytokine subfamily E, member 1; Spp1: Secreted phosphoprotein 1; Tgfb1: Transforming growth factor, beta 1; TNF: Tumor necrosis factor (TNF superfamily, member 2); TNFrsf1a: Tumor necrosis factor receptor superfamily, member 1a; TNFrsf1b: Tumor necrosis factor receptor superfamily, member 1b; Tollip: Toll interacting protein; Xcr1: Chemokine (C motif) receptor 1

\section{Acknowledgements}

This study was supported, in part, by the National Institutes of Health/ National Institute on Drug Abuse and National Institute on Alcohol Abuse and Alcoholism (R01 DA007058, R01 DA 026356, K02 DA016149, and RC2 AA019415 to SLC).

\section{Author details}

'Institute of Neurolmmune Pharmacology, Seton Hall University, South Orange, NJ, 07079, USA. ²Department of Biological Science, Seton Hall University, South Orange, NJ, 07079, USA.

\section{Authors' contributions}

$\mathrm{NFH}$ participated in the experimental design, coordination, tissue collection, and pilot PCR array studies, and was the primary drafter of the manuscript. XM participated in tissue collection, carried out the PCR array studies, and provided input on the manuscript. EFL carried out the cytokine/chemokine protein measurement studies, and provided input on the manuscript. SLC conceived the idea of the study, designed and coordinated the experiments and assays, and conducted blind studies, data analysis, and manuscript preparation. All authors read and approved the final manuscript.

\section{Competing interests}

The authors declare that they have no competing interests.

Received: 1 May 2011 Accepted: 4 January 2012

Published: 4 January 2012

\section{References}

1. Schletter J, Heine H, Ulmer AJ, Rietschel ET: Molecular mechanisms of endotoxin activity. Arch Microbiol 1995, 164:383-389.

2. Cybulsky AV, Papillon J, McTavish AJ: Complement activates phospholipases and protein kinases in glomerular epithelial cells. Kidney Int 1998, 54:360-372.

3. Fujihara M, Muroi M, Tanamoto K, Suzuki T, Azuma H, Ikeda H: Molecular mechanisms of macrophage activation and deactivation by lipopolysaccharide: roles of the receptor complex. Pharmacol Ther 2003, 100:171-194.

4. Rosenberger CM, Scott MG, Gold MR, Hancock RE, Finlay BB: Salmonella typhimurium infection and lipopolysaccharide stimulation induce similar changes in macrophage gene expression. J Immunol 2000, 164:5894-5904.
5. Turnbull AV, Rivier CL: Regulation of the hypothalamic-pituitary-adrenal axis by cytokines: actions and mechanisms of action. Physiol Rev 1999, 79:1-71.

6. Szabo G: [Results of recent research on opthalmic disease of tuberculous origin]. Szemeszet 1951, 88:22-28.

7. del Fresno C, Garcia-Rio F, Gomez-Pina V, Soares-Schanoski A, FernandezRuiz I, Jurado T, Kajiji T, Shu C, Marin E, Gutierrez del Arroyo A, et al: Potent Phagocytic Activity with Impaired Antigen Presentation Identifying Lipopolysaccharide-Tolerant Human Monocytes: Demonstration in Isolated Monocytes from Cystic Fibrosis Patients. The Journal of Immunology 2009, 182:6494-6507.

8. Foster S, Medzhitov R: Gene-specific control of the TLR-induced inflammatory response. Clinical Immunology 2009, 130:7-15.

9. Biswas SK, Tergaonkar V: Myeloid differentiation factor 88-independent Toll-like receptor pathway: Sustaining inflammation or promoting tolerance? The International Journal of Biochemistry \& Cell Biology 2007, 39:1582-1592.

10. Vigorito M, LaShomb AL, Chang SL: Spatial learning and memory in HIV-1 transgenic rats. J Neuroimmune Pharmacol 2007, 2:319-328.

11. Dobrovolskaia MA, Vogel SN: Toll receptors, CD14, and macrophage activation and deactivation by LPS. Microbes Infect 2002, 4:903-914

12. Fan H, Cook JA: Molecular mechanisms of endotoxin tolerance. $J$ Endotoxin Res 2004, 10:71-84.

13. Cavaillon J-M, Adib-Conquy M: Critical Care 2006, 10:233.

14. Biswas SK, Bist P, Dhillon MK, Kajiji T, Del Fresno C, Yamamoto M, LopezCollazo E, Akira S, Tergaonkar V: Role for MyD88-independent, TRIF pathway in lipid A/TLR4-induced endotoxin tolerance. J Immunol 2007 179:4083-4092.

15. Foster SL, Hargreaves DC, Medzhitov R: Gene-specific control of inflammation by TLR-induced chromatin modifications. Nature 2007.

16. Dobrovolskaia MA, Medvedev AE, Thomas KE, Cuesta N, Toshchakov V, Ren T, Cody MJ, Michalek SM, Rice NR, Vogel SN: Induction of in vitro reprogramming by Toll-like receptor (TLR)2 and TLR4 agonists in murine macrophages: effects of TLR "homotolerance" versus "heterotolerance" on NF-kappa B signaling pathway components. J Immunol 2003, 170:508-519.

17. Medvedev AE, Kopydlowski KM, Vogel SN: Inhibition of lipopolysaccharideinduced signal transduction in endotoxin-tolerized mouse macrophages: dysregulation of cytokine, chemokine, and toll-like receptor 2 and 4 gene expression. J Immunol 2000, 164:5564-5574.

18. Cavaillon JM, Adrie C, Fitting C, Adib-Conquy M: Endotoxin tolerance: is there a clinical relevance? J Endotoxin Res 2003, 9:101-107.

19. Monneret G, Venet F, Pachot A, Lepape A: Monitoring immune dysfunctions in the septic patient: a new skin for the old ceremony. Mol Med 2008, 14:64-78.

20. Fauci AS: Host factors and the pathogenesis of HIV-induced disease. Nature 1996, 384:529-534.

21. Giuseppe Pantaleo CG, Anthony SFauci: The Immunopathogenesis of Human Immunodeficiency Virus Infection. N Engl J Med 1993, 328:327-335.

22. Cicala C, Arthos J, Selig SM, Dennis G Jr, Hosack DA, Van Ryk D, Spangler ML, Steenbeke TD, Khazanie P, Gupta N, et al: HIV envelope induces a cascade of cell signals in non-proliferating target cells that favor virus replication. Proc Natl Acad Sci USA 2002, 99:9380-9385.

23. Clapham PR, McKnight A: HIV-1 receptors and cell tropism. Br Med Bull 2001, 58:43-59

24. Jiang J, Aiken C: Maturation of the viral core enhances the fusion of HIV1 particles with primary human $T$ cells and monocyte-derived macrophages. Virology 2006, 346:460-468.

25. Torensma R, Figdor CG: The Achilles' heel of HIV. Med Hypotheses 2002 58:386-387.

26. Verani A, Gras G, Pancino G: Macrophages and HIV-1: dangerous liaisons. Mol Immunol 2005, 42:195-212.

27. Palella FJ Jr, Delaney KM, Moorman AC, Loveless MO, Fuhrer J, Satten GA, Aschman DJ, Holmberg SD: Declining morbidity and mortality among patients with advanced human immunodeficiency virus infection. HIV Outpatient Study Investigators. N Engl J Med 1998, 338:853-860.

28. Jones $L E$, Perelson AS: Opportunistic infection as a cause of transient viremia in chronically infected HIV patients under treatment with HAART. Bull Math Biol 2005, 67:1227-1251. 
29. Vigano A, Trabattoni D, Schneider L, Ottaviani F, Aliffi A, Longhi E, Rusconi S, Clerici M: Failure to eradicate HIV despite fully successful HAART initiated in the first days of life. J Pediatr 2006, 148:389-391.

30. Yim HCLJ, Lau JS, Lau AS: HIV-1 Tat dysregulation of lipopolysaccharideinduced cytokine responses: microbial interactions in HIV infection. AIDS 2009, 23:1473-1484.

31. Mirani MEl, Volpi S, Hiroi N, Chrousos GP, Kino T: HIV-1 protein Vpr suppresses IL-12 production from human monocytes by enhancing glucocorticoid action: potential implications of Vpr coactivator activity for the innate and cellular immunity deficits observed in HIV-1 infection. J Immunol 2002, 169(11):6361-6368.

32. Reid W, Sadowska M, Denaro F, Rao S, Foulke J Jr, Hayes N, Jones O, Doodnauth D, Davis $H$, Sill A, et al: An HIV-1 transgenic rat that develops HIV-related pathology and immunologic dysfunction. Proc Natl Acad Sci USA 2001, 98:9271-9276.

33. Chang SL, Ocasio Frank, Beltran Jose: Immunodeficient parameters in the HIV-1 transgenic rat model. Am J Infect Diseases 2007, 3:6.

34. Chang SL, Michael Vigorito: Role of HIV-1 infection in addictive behavior: A study of an HIV-1 transgenic rat model. Am J Infect Diseases 2006, 2:9.

35. Joshi PC, Raynor R, Fan X, Guidot DM: HIV-1-transgene expression in rats decreases alveolar macrophage zinc levels and phagocytosis. Am J Respir Cell Mol Biol 2008, 39:218-226.

36. Chang SL, Beltran JA, Swarup S: Expression of the mu opioid receptor in the human immunodeficiency virus type 1 transgenic rat model. J Virol 2007, 81:8406-8411.

37. Peng J, Vigorito M, Liu X, Zhou D, Wu X, Chang SL: The HIV-1 transgenic rat as a model for HIV-1 infected individuals on HAART. J Neuroimmunol 2010, 218:94-101.

38. Lund AK, Lucero J, Herbert L, Liu Y, Naik JS: Human immunodeficiency virus- transgenic rats exhibit pulmonary hypertension. Am J Physiol Lung Cell Mol Physiol 2011

39. Basselin M, Ramadan E, Igarashi M, Chang L, Chen M, Kraft AD, Harry GJ, Rapoport SI: Imaging upregulated brain arachidonic acid metabolism in HIV-1 transgenic rats. J Cereb Blood Flow Metab 2011, 31:486-493.

40. Lester R, Yao X, Ball T, McKinnon L, WR O, Kaul R, Wachihi C, Jaoko W Rosenthal K, Plummer F: HIV-1 RNA Dysregulates the Natural TLR Response to Subclinical Endotoxemia in Kenyan Female Sex-Workers. PLOS ONE 2009, 4

41. Lester R, Yao X, Ball T, McKinnon L, Kaul R: Toll-like-receptor expression and responsiveness are increased in viraemic HIV-1 infection. AIDS 2008, 22:685-694.

42. Westendorp MO, Shatrov VA, Schulze-Osthoff K, Frank R, Kraft M, Los M, Krammer PH, Droge W, Lehmann V: HIV-1 Tat potentiates TNF-induced NF-kappa $B$ activation and cytotoxicity by altering the cellular redox state. EMBO J 1995, 14:546-554.

43. Ansari AW, Heiken H, Moenkemeyer M, Schmidt RE: Dichotomous effects of C-C chemokines in HIV-1 pathogenesis. Immunol Lett 2007, 110:1-5.

44. Angus D, Linde-Zwirble W, Lidicker J, Clermont G, Carcillo J, Pinsky M: Epidemiology of severe sepsis in the United States: Analysis of incidence, outcome, and associated costs of care. Crit Care Med 2001, 29:1303-1310.

45. Levy JA: HIV and the pathogenesis of AIDS. 2 edition. Washington, D.C.: ASM Press; 1998.

46. Chen R, Zhou H, Beltran J, Malellari L, Chang S: Differential expression of cytokines in the brain and serum during endotoxin tolerance. Journal of Neuroimmunology 2005, 163:53-72.

47. DeRisi J, Penland L, Brown PO, Bittner ML, Meltzer PS, Ray M, Chen Y, Su YA, Trent JM: Use of a cDNA microarray to analyse gene expression patterns in human cancer. Nat Genet 1996, 14:457-460.

48. DeRisi JL, lyer VR, Brown PO: Exploring the metabolic and genetic control of gene expression on a genomic scale. Science 1997, 278:680-686.

49. Linde T, Sandhagen B, Backman U, Fellstrom B: Altered flow properties of blood and increased plasma fibrinogen in cyclosporin-treated renal allograft recipients. Nephrol Dial Transplant 1999, 14:1525-1529.

50. Montgomery CP, Daum RS: Transcription of inflammatory genes in the lung after infection with community-associated methicillin-resistant Staphylococcus aureus: a role for panton-valentine leukocidin? Infect Immun 2009, 77:2159-2167.

51. Sudarsanam P, lyer VR, Brown PO, Winston F: Whole-genome expression analysis of snf/swi mutants of Saccharomyces cerevisiae. Proc Natl Acad Sci USA 2000, 97:3364-3369.
52. Wellmann A, Thieblemont $C$, Pittaluga S, Sakai A, Jaffe ES, Siebert $P$, Raffeld M: Detection of differentially expressed genes in lymphomas using CDNA arrays: identification of clusterin as a new diagnostic marker for anaplastic large-cell lymphomas. Blood 2000, 96:398-404.

53. Draisma A, Pickkers $P$, Bouw MP, van der Hoeven JG: Development of endotoxin tolerance in humans in vivo. Crit Care Med 2009, 37:1261-1267.

54. Mages J, Dietrich $H$, Lang R: A genome-wide analysis of LPS tolerance in macrophages. Immunobiology 2007, 212:723-737.

55. Biswas SK, Lopez-Collazo E: Endotoxin tolerance: new mechanisms, molecules and clinical significance. Trends Immunol 2009, 30:475-487.

56. Boasso A, Shearer GM, Chougnet C: Immune dysregulation in human immunodeficiency virus infection: know it, fix it, prevent it? J Intern Med 2009, 265:78-96.

57. Capobianchi MR: Induction of lymphomonocyte activation by HIV-1 glycoprotein gp120. Possible role in AIDS pathogenesis. J Biol Regul Homeost Agents 1996, 10:83-91.

58. Herbeuval JP, Shearer GM: Are blockers of gp120/CD4 interaction effective inhibitors of HIV-1 immunopathogenesis? AIDS Rev 2006, 8:3-8.

59. Schols D, De Clercq E: Human immunodeficiency virus type $1 \mathrm{gp} 120$ induces anergy in human peripheral blood lymphocytes by inducing interleukin-10 production. J Virol 1996, 70:4953-4960.

60. Wilson SE, Habeshaw JA, Addawe MA, Hounsell EF, Oxford JS: HIV type 1 envelope glycoprotein 120 carboxy-terminal peptide-induced human $T$ cell lines selectively suppress heterogeneous proliferative T cell responses to soluble antigens. AIDS Res Hum Retroviruses 1997 13:1313-1324.

61. Chen J, Ivashkiv LB: IFN-gamma abrogates endotoxin tolerance by facilitating Toll-like receptor-induced chromatin remodeling. Proc Nat Acad Sci USA 2010, 107:19438-19443.

62. Mahajan SD, Schwartz SA, Shanahan TC, Chawda RP, Nair MP: Morphine regulates gene expression of alpha- and beta-chemokines and their receptors on astroglial cells via the opioid mu receptor. J Immunol 2002, 169:3589-3599.

63. Martin-Garcia J, Kolson DL, Gonzalez-Scarano F: Chemokine receptors in the brain: their role in HIV infection and pathogenesis. AIDS 2002, 16:1709-1730.

64. Bachis A, Cruz MI, Mocchetti I: M-tropic HIV envelope protein gp120 exhibits a different neuropathological profile than T-tropic gp120 in rat striatum. Eur J Neurosci 2010, 32:570-578.

65. Starr-Spires LD, Collman RG: HIV-1 entry and entry inhibitors as therapeutic agents. Clin Lab Med 2002, 22:681-701.

doi:10.1186/1742-2094-9-3

Cite this article as: Homji et al:: Endotoxin-induced cytokine and

chemokine expression in the HIV-1 transgenic rat. Journal of Neuroinflammation 2012 9:3.

\section{Submit your next manuscript to BioMed Central and take full advantage of:}

- Convenient online submission

- Thorough peer review

- No space constraints or color figure charges

- Immediate publication on acceptance

- Inclusion in PubMed, CAS, Scopus and Google Scholar

- Research which is freely available for redistribution

Submit your manuscript at www.biomedcentral.com/submit
C Biomed Central 